\title{
Isolasi Gelatin dari Limbah Tulang Ikan Nila (Oreochromis Niloticus): Pengaruh Suhu dan Waktu Ekstraksi
}

\author{
Putra Capriyanda ${ }^{1, a}$, Muhammad Mujiburohman ${ }^{1, b, *}$ \\ 1 Jurusan Teknik Kimia, Fakultas Teknik, Universitas Muhammadiyah Surakarta, \\ Jl.A. Yani Pabelan Kartasura Tromol Pos 1 Surakarta 57102, Indonesia \\ E-mail: aputracapriyanda10@gmail.com, bmmujiburohman@ums.ac.id (*Corresponding author)
}

\begin{abstract}
Gelatin is a type of protein derivate from collagen fibers that can be extracted from bone. This study aims to determine the effects of temperature and extraction time on the extract of isolated gelatin from tilapia fish bones. Gelatin isolation stages include degreasing using water, demineralization with a ratio of 1:10 (w/v) tilapia bone powder and distilled water, and extraction. The extraction used distilled water with a ratio of ossein and distilled water $1: 10(\mathrm{w} / \mathrm{v})$. The extraction temperature was varied at $50^{\circ} \mathrm{C}, 60^{\circ} \mathrm{C}$, and $85^{\circ} \mathrm{C}$, for 1 hour, 3 hours, and 5 hours. The highest yield of gelatin was obtained at a temperature of $60^{\circ} \mathrm{C}$ in 1 hour, i.e. $0.86 \mathrm{~g}$ (yield of $9.55 \%$ ). The test on gelatin obtained the gelatin viscosity from 1,442-2,844 $\mathrm{cP}$, gelatin $\mathrm{pH}$ $5,2-6,8$, and ash content of 2,143-2,778\%. The FTIR test showed that the product contained amine and carbonyl functional groups at the wavelengths of $1206.53 \mathrm{~cm}^{-1}, 1270.18 \mathrm{~cm}-1$, and $1286.58 \mathrm{~cm}^{-1}$. The gelatin obtained meets the commercial gelatin quality standards.
\end{abstract}

Keywords: gelatin, collagen, tilapia fishbone, viscosity.

EQUILIBRIUM Volume 4 No.2 December 2020

Online at http:/ / equilibrium.ft.uns.ac.id 


\section{Pendahuluan}

Gelatin adalah sejenis derivate protein dari serat kolagen yang dapat diekstraksi dari tulang. Gelatin memiliki karakter yang unik antara lain kemampuan untuk berbalik bentuk dari sol menjadi gel, bersifat amfoter, dan menjaga sifat koloid. Produk ini digunakan untuk keperluan pengolahan pangan, kosmetika, dan media mikrobiologis. Gelatin larut dalam air, asam asetat, dan pelarut alkohol seperti gliserol, propilen glycol, sorbitol dan manitol, tetapi tidak larut dalam aseton, karbon tetraklorida, benzen, dan petroleum eter. Menurut Norland (1997), gelatin mudah larut pada suhu $71,1^{\circ} \mathrm{C}$ dan cenderung membentuk gel pada suhu $48,9^{\circ} \mathrm{C}$. Sedangkan menurut Montero (2000), pemanasan yang dilakukan untuk melarutkan gelatin sekurangkurangnya $49^{\circ} \mathrm{C}$ atau biasanya pada suhu $60-70^{\circ} \mathrm{C}$.

Kolagen, serat yang umumnya mengandung gelatin, merupakan komponen struktural utama pada serat-serat jaringan pengikat, berwarna putih, dan terdapat di dalam semua jaringan dan organ hewan, serta berperan penting dalam penyusun bentuk tubuh. Pada ikan, kolagen terdapat pada kulit, tulang, dan kartilago. Kolagen dapat larut dalam pelarut alkali maupun asam, sehingga kedua pelarut ini dimungkinkan untuk digunakan dalam proses produksi gelatin (Bennion, 1980). Di bawah mikroskop, jaringan tersebut terlihat sebagai serat putih buram yang dikelilingi oleh protein lain dan mucopolysaccharida (Poppe, 1992). Perlakuan alkali ataupun asam menyebabkan kolagen mengembang dan menyebar.

Produksi gelatin dari tulang ikan yang sangat besar dapat membantu pemerintah dalam meningkatkan pendapatan domestik brutonya. Kebutuhan gelatin di Indonesia saat ini banyak diimpor dari beberapa negara seperti Cina, Australia, dan beberapa negara Eropa. Menurut data Biro Pusat Statistik (2018) jumlah impor gelatin mengalami peningkatan setiap tahun. Impor gelatin dari tahun 2013 sampai 2017 berturutturut sebanyak 3.149.776 ton, 3.567.824 ton, 3.771.040 ton, 3.872.104 ton, dan 3.990.152 ton.

Selama ini limbah dari tulang ikan terutama tulang ikan nila merah belum dimanfaatkan secara optimal, yaitu hanya digunakan untuk bahan pembuatan pakan atau pupuk sehingga nilai ekonomisnya masih rendah (Hariyanto dan Sambudi, 2010). Ikan nila merah adalah sejenis ikan konsumsi air tawar. Ikan ini diintroduksi dari Afrika, tepatnya Afrika bagian timur, pada tahun 1969, dan kini menjadi ikan peliharaan yang popular di kolam-kolam air tawar, sungai, dan danau Indonesia (Rachmatun, 2009). Pada tulang ikan nila merah ini terkandung protein yang mengandung kolagen cukup tinggi yang berpotensi untuk dijadikan gelatin (Maryani, 2010).

Berdasarkan beberapa pertimbangan di atas, ekstraksi gelatin dari tulang ikan nila merah penting dilakukan sebagai upaya pemanfaatan limbah pengolahan ikan. Tujuan dari penelitian ini adalah untuk mempelajari proses isolasi gelatin dari tulang ikan nila. Secara khusus, pengaruh suhu dan waktu ekstraksi terhadap hasil ekstraksi diinvestigasi, dan menentukan kondisi optimal isolasi gelatin dari tulang ikan nila.

\section{Metode Penelitian}

Bahan-bahan yang digunakan dalam penelitian ini adalah natrium hidroksida $(\mathrm{NaOH}) 1 \mathrm{~N}$, air suling $\left(\mathrm{H}_{2} \mathrm{O}\right)$, asam klorida ( $\mathrm{HCl}$ ) 4\%, dan sampel berupa tulang ikan nila. Alat-alat yang digunakan mencakup satu unit alat pengaduk mekanik, gelas kimia $2000 \mathrm{~mL}$, gelas kimia $500 \mathrm{~mL}$, gelas kimia $250 \mathrm{~mL}$, gelas kimia $100 \mathrm{~mL}$, cawan porselin, cawan petri, waterbath, oven, labu ukur $1000 \mathrm{~mL}$, corong kaca, timbangan digital, desikator, statif, klem, kompor listrik, pH meter, thermometer, furnace, blender, ball pipet, piknometer $10 \mathrm{~mL}$, kertas saring, kain flannel, gelas ukur $100 \mathrm{~mL}$, gelas ukur $50 \mathrm{~mL}$, pipet tetes, batang pengaduk, pompa vakum, dan spatula. Tahapan penelitian terdiri atas degreasing, demineralisasi, ekstraksi, pengeringan, dan analisis hasil.

Merujuk pada penelitian Qurrataayun 2018, degreasing tulang ikan nila dilakukan dengan cara direndam dalam air mendidih selama 1 jam sambil diaduk-aduk dengan beberapa kali pergantian air, kemudian tulang ikan nila ditiriskan dan dijemur. Setelah itu, tulang ikan nila dihaluskan dengan menggunakan blender hingga berukuran 100 mesh. Demineralisasi bertujuan untuk menghilangkan kalsium, dan garam-garam mineral yang ada dalam tulang ikan nila. Tulang ikan nila yang telah dihaluskan dengan menggunakan blender, kemudian direndam dalam larutan natrium hidroksida $1 \mathrm{~N}$ sebanyak 1 liter dengan perbandingan $1: 10 \mathrm{~g} / \mathrm{mL}$ selama 8 jam sambil terus diaduk dan menghasilkan ossein (tulang lunak) dengan kecepatan pengadukan $200 \mathrm{rpm}$. Ossein yang direndam disaring dan dicuci dengan asam klorida $(\mathrm{HCl})$ 4\%. Ossein yang ber-pH netral diekstraksi dengan menggunakan asam asetat dengan variasi suhu ekstraksi dan waktu ekstraksi.

Proses ekstraksi dilakukan dengan menggunakan waterbath pada suhu $50^{\circ} \mathrm{C}, 60^{\circ} \mathrm{C}$, dan $85^{\circ} \mathrm{C}$ selama 1 jam, 3 jam, dan 5 jam. Setelah diesktraksi, ossein disaring menggunakan kertas saring (Qurrataayun, 2018). Hasil ekstraksi berupa cairan yang didapat dari proses penyaringan, kemudian dituang ke dalam cawan porselin dan dikeringkan pada suhu oven $65^{\circ} \mathrm{C}$ selama 12 jam (Qurrataayun, 2018). Analisis hasil meliputi pengujian viskositas, uji $\mathrm{pH}$, rendemen, kadar abu, dan FT-IR. 


\section{Hasil dan Pembahasan}

\section{a. Viskositas}

Viskositas atau kekentalan sampel gelatin yang diuji sebagai pengaruh suhu dan waktu ekstraksi dengan konsentrasi 1,2\% ditunjukkan pada Gambar 1. Semakin tinggi suhu, viskositas gelatin semakin rendah. Hal ini dikarenakan struktur gelatin mudah terdegradasi pada suhu tinggi, menjadi rantai yang lebih pendek, sehingga lebih encer.

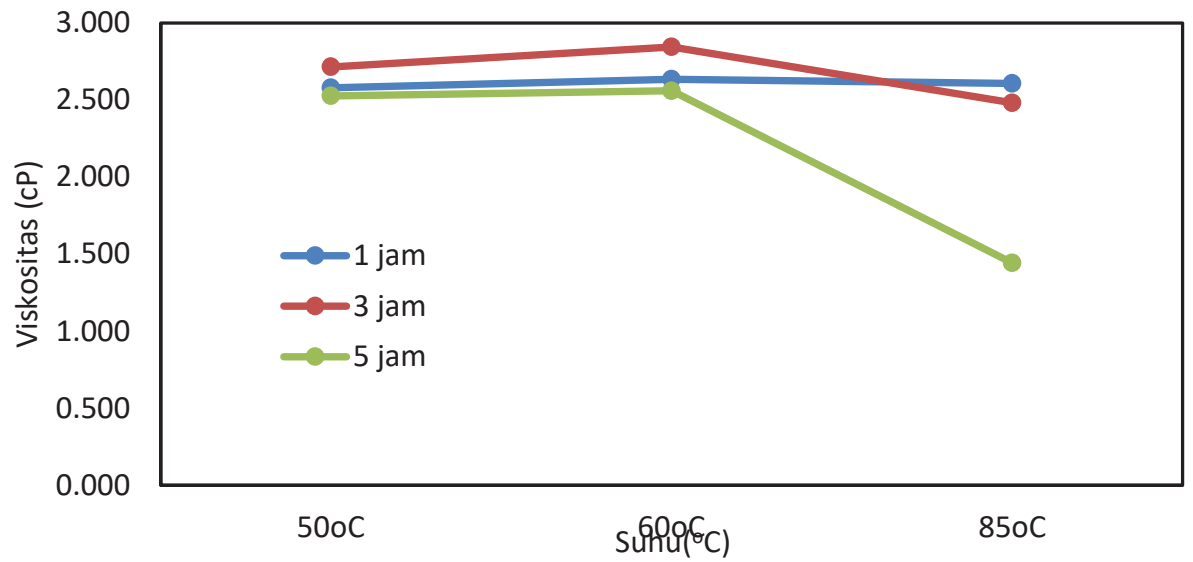

Gambar 1. Viskositas gelatin sebagai fungsi suhu dan waktu ekstraksi.

Pada kisaran suhu dan waktu ekstraksi yang dipelajari, viskositas gelatin berkisar 1,442-3,442 cP, sudah memenuhi viskositas Standar Mutu Gelatin (GMIA, 2012), yaitu 1,5-7,5 cP.

\section{b. $\mathrm{pH}$}

Gambar 2 memperlihatkan pengaruh suhu dan waktu ekstraksi terhadap pH gelatin. Pada kisaran suhu dan waktu ekstraksi yang dipelajari, gelatin yang dihasilkan memiliki $\mathrm{pH}$ antara 5,2-6,8. Kisaran pH gelatin ini memenuhi syarat sebagian dari Standar Mutu Gelatin (GMIA, 2012), bahwa pH gelatin komersial sebesar 3,86,0. Waktu ekstraksi 3 jam pada berbagai suhu memberikan $\mathrm{pH}$ gelatin di bawah 6,0. $\mathrm{pH}$ gelatin sebaiknya rendah karena lebih tahan terhadap kontaminasi mikroorganisme, dan baik digunakan untuk produk sirup asam, juice, dan mayones (Nada, 2017).

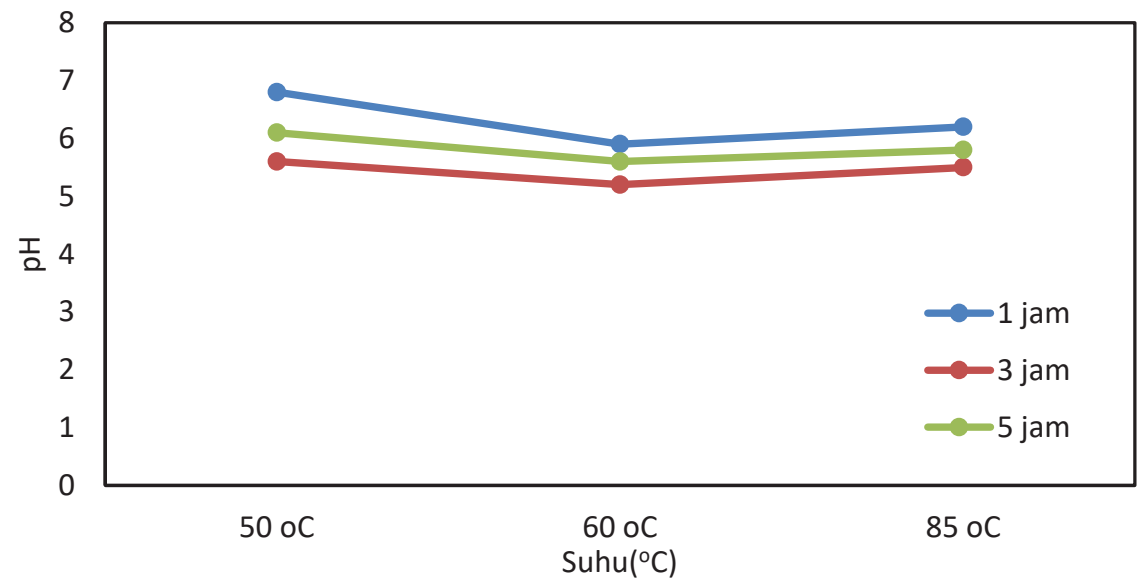

Gambar 2. Pengaruh suhu dan waktu ekstraksi terhadap pH gelatin

Isolasi Gelatin dari Limbah Tulang Ikan Nila (Oreochromis Niloticus): Pengaruh Suhu dan Waktu Ekstraksi 


\section{c. Rendemen}

Rendemen merupakan persentase berat gelatin yang dihasilkan terhadap berat awal bubuk tulang ikan nila yang digunakan. Rendemen gelatin dari limbah tulang ikan nila ditunjukkan pada Gambar 3. Terlihat bahwa pada waktu ekstraksi 3 jam dan 5 jam, semakin tinggi suhu maka rendemen semakin turun. Hal ini dimungkinkan karena semakin tinggi suhu dan lama waktu ekstraksi, gelatin yang diperoleh ikut terdegradasi. Rendemen tertinggi diperoleh pada suhu ekstraksi $60^{\circ} \mathrm{C}$ dengan waktu ekstraksi 1 jam, sebesar 9,55\%.

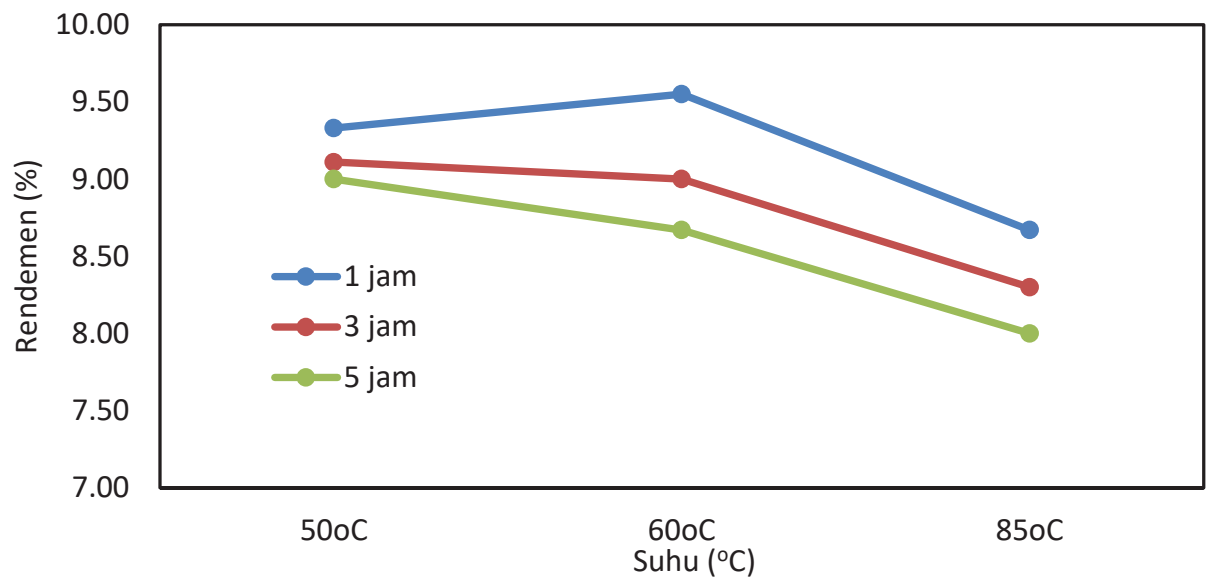

Gambar 3. Pengaruh suhu dan waktu ekstraksi terhadap rendemen gelatin.

\section{d. Kadar abu}

Hasil pengujian kadar abu pada gelatin dari tulang ikan nila ditunjukkan pada Gambar 4. Pada waktu ekstraksi 1 jam dan 5 jam, kadar abu cenderung turun dengan kenaikan suhu. Hal ini disebabkan protein mengalami denaturasi, menjadikan ikatan kimia protein rusak dan tidak memiliki ikatan yang kuat dengan mineral, bahan pembentuk abu. Pada kisaran suhu dan waktu ekstraksi yang dipelajari, semua kadar abu di atas $2 \%$, melebihi kadar abu maksimal Standar Mutu Gelatin, yaitu 2\%.

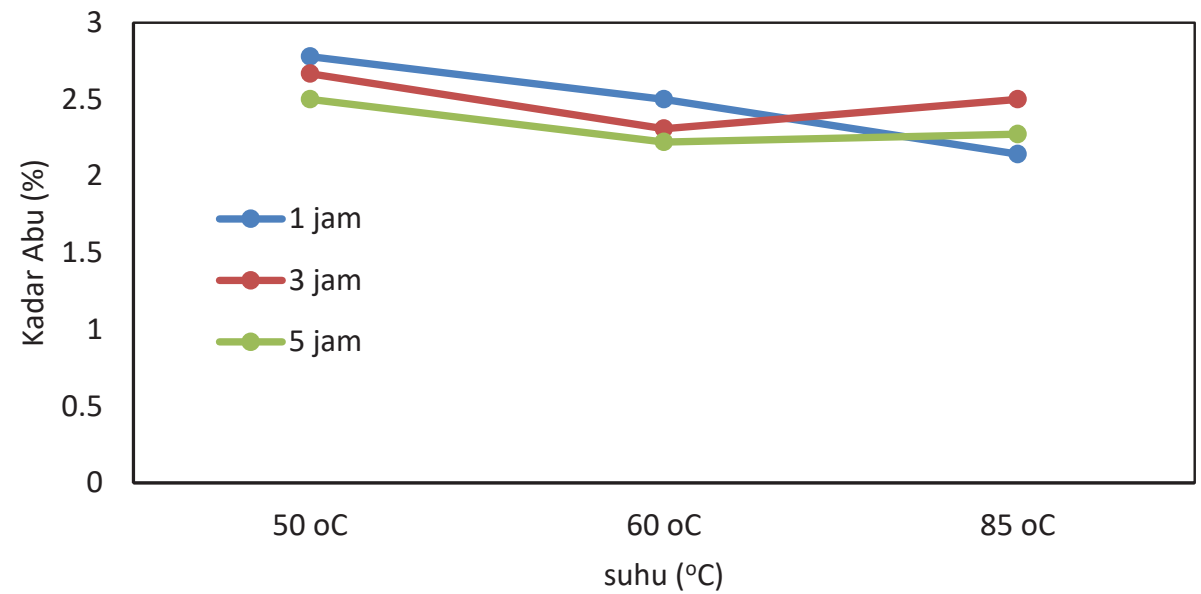

Gambar 4. Kadar abu pada gelatin sebagai fungsi suhu dan waktu ekstraksi.

\section{e. FT-IR}

Hasil uji FT-IR ditunjukkan pada Gambar 5. Analisis sampel dengan FT-IR terjadi pada bilangan gelombang 4650-450 $\mathrm{cm}^{-1}$. Daerah resapan dengan bilangan gelombang $1180-1360 \mathrm{~cm}^{-1}$ adalah gugus C-N amida, bilangan gelombang 3300-3500 $\mathrm{cm}^{-1}$ adalah gugus $\mathrm{N}-\mathrm{H}$ amida, dan bilangan gelombang $1690-1760 \mathrm{~cm}^{-1}$ adalah gugus $\mathrm{C}=\mathrm{O}$ karbonil. Pada penelitian ini gugus $\mathrm{C}-\mathrm{N}$ terdeteksi pada bilangan gelombang $1206,53 \mathrm{~cm}^{-}$ 1; $1270,18 \mathrm{~cm}^{-1}$; dan 1286,58 $\mathrm{cm}^{-1}$. Gugus N-H terdeteksi pada bilangan gelombang 3418,97 $\mathrm{cm}^{-1}$; sedangkan gugus $\mathrm{C}=\mathrm{O}$ terdeteksi pada bilangan gelombang $1660,78 \mathrm{~cm}^{-1}$ dan $1709 \mathrm{~cm}^{-1}$. Terdeteksinya gugus amida, dan karbonil mengkonfirmasi bahwa gelatin berhasil terbentuk. 


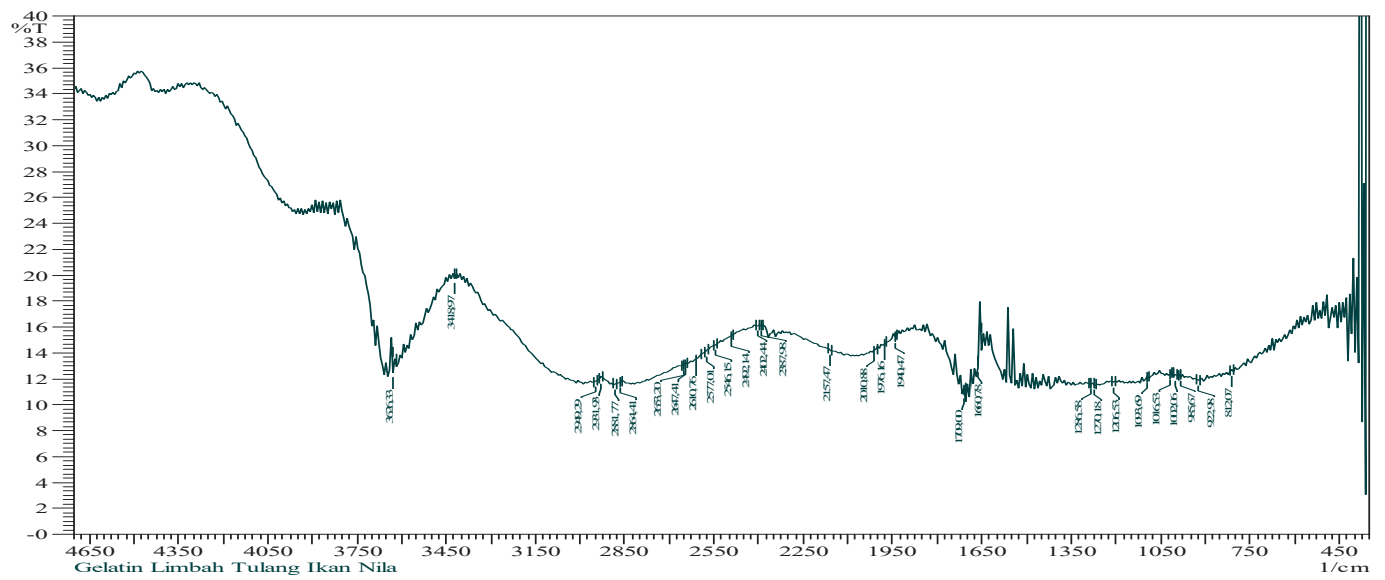

Gambar 5. Hasil analisis FT-IR pada suhu $60^{\circ} \mathrm{C}$ dan waktu 3 jam.

\section{Kesimpulan}

Proses isolasi gelatin dari tulang ikan nila dilakukan dengan cara degreasing, demineralisasi, ekstraksi, dan pengeringan. Suhu ekstraksi berpengaruh terhadap karakteristik gelatin, sedangkan waktu ekstraksi berpengaruh terhadap nilai rendamen gelatin dan tidak berpengaruh signifikan terhadap karakteristik gelatin berupa $\mathrm{pH}$, viskositas, dan kadar abu. Kondisi optimal ekstraksi gelatin dari limbah tulung ikan nila diperoleh pada suhu $60^{\circ} \mathrm{C}$ dengan waktu 1 jam, dengan rendamen gelatin sebesar 9,55\%.

\section{Referensi}

[1]. Norland, R.E. 1997. Fish Gelatin: Technical Aspects and Applications, dalam Band, S.J. (Ed.). Photographic Gelatin. London: Royal Photographic Society.

[2]. Montero, P. \& Gomez-Guillen, M.C. 2000. Extracting conditions for megrim (Lepidorhombus boscii) skin collagen affect functional properties of the resultant gelatin. Journal of Food Science, 65: 536-537.

[3]. Bennion, M. 1980. The Science of Food. New York: John Willey and Sons.

[4]. Poppe, J. 1992. Gelatine, dalam Imeson, A. (Ed.). Thickening and Gelling Agents for Food. London: Blackie Academic and Proffesional.

[5]. Hariyanto, \& Sambudi, Y.J. 2010. Pembuatan Gelatin dari Tulang Ikan Air Tawar (Anabantidae). Tugas Akhir. Surakarta: FT UNS.

[6]. Rachmatun, S. 2009. Nila. Jakarta: Penebar Swadaya.

[7]. Maryani, Surti, T., \& Ibrahim, R. 2010. Aplikasi Gelatin Tulang Ikan Nila Merah (Oreochronis niloticus) Terhadap Mutu Permen Jelly. Jurnal Saintek Perikanan, 6 (1): 62-68.

[8]. Qurrataayun, S. 2018. Pengaruh Asam, Basa, Metode Ekstraksi dan Metode Pengeringan Terhadap Viskositas Gelatin Dari Sisik Ikan Bandeng (Chanos Chanos). Skripsi. Fakultas Kedokteran dan Ilmu Kesehatan. UIN Allauddin. Makasar.

[9]. Nada, U. 2017. Ekstraksi dan Karakterisasi Gelatin Kulit Kambing Peranakan Etawah Menggunakan Hidrolisis Asam Klorida Pada Kulit Yang Mengalami Proses Buang Bulu Secara Pemanasan. Fakultas Kedokteran Dan Ilmu Farmasi. UIN Syarif Hidayatullah. Jakarta 
